\title{
INHERITANCE OF QUALITATIVE MORPHOLOGICAL TRAITS AND VARIATION OF QUANTITATIVE AGRONOMIC TRAITS OF ENSET (ENSETE VENTRICOSUM (WELW.) CHEESMAN) CLONES OBTAINED FROM WOLAITA ZONE, SOUTHERN ETHIOPIA
}

\author{
Abraham Bosha and *Mesfin Kebede Gessese \\ Wolaita Sodo University, College of Agriculture, P O Box 138, Sodo, SNNPRS, Ethiopia \\ ${ }^{*}$ corresponding author Email: mesfin04@yahoo.com
}

\begin{abstract}
The present cultivated enset clonal landraces in Ethiopia originated from few wild progenitors. However, enset has a mixed mode of reproduction in which, the wild enset reproduces sexually through seeds, while cultivated enset is generally propagated vegetatively. The objective of this study was to understand the genetic structures of enset cultivars and estimate their genetic variability by evaluating the morphological data generated from progenies of cultivated and wild enset clones. Hence, seeds collected from six cultivated and four wild enset genotypes were used for this study. Data on four qualitative and six quantitative morphological traits were recorded from the progenies of the 10 enset genotypes. Progenies of seven enset genotypes segregated with 3:1 genetic ratio while progenies of the remaining genotypes segregated differently for the qualitative traits considered. With regard to the quantitative traits, the progenies of the 10 enset genotypes differed significantly for five of the six traits except pseudostem length. Generally the cultivated clones performed better than the wild types. This study demonstrated the possibility of creating genetic variation through selfing of the existing clones of enset for traits of interest and makes improvements either through selection or crossing the elite types to develop novel cultivars.
\end{abstract}

Keywords: Chi-squared, Genetic ratios, Progenies, Selfing, Variability analysis

\section{INTRODUCTION}

Enset is considered mainly as an African crop that currently provides the staple food for one-fifth of Ethiopian population (Yemataw, et al., 2017; Borell, et al., 2019). It is a large perennial monocarpic herbaceous plant, similar in form to the related bananas of the genus Musa. Unlike to Musa species that has $\mathrm{n}=7,10$, and 11 set of chromosomes with various ploidy levels, Enset is a diploid plant with chromosome number $2 \mathrm{n}=18$ with no record of polyploidy (Diro, et al., 2003). Ensete is geographically distributed in the wild in many parts of Sub-Saharan Africa and Asia with about 6 - 7 species (Simmonds, 1962; Pursglove, 1972) in which Ensete ventricosum species is cultivated only in its native indigenous farming systems of 
2

south and south-western Ethiopia (Brandt et al., 1997). The highlands of southern part of the country form the geographical centre of the crop cultivation (Vavilov and Rodin, 1997) and the various ethnic groups in this region recognize and exploit many enset landraces.

The enset planting is complex, supports a denser population than any other farming system (Brandt et al., 1997). The crop has been domesticated and is cultivated for food, animal feed and fibre (Bezuneh et al., 1967), ensuring food security for about $20 \%$ of the human population in Ethiopia that depend on enset as one of the staple food sources. It is Ethiopia's most important root crop, a traditional staple crop in the densely populated parts of the country (George, 2004). This multipurpose culture crop used as source of large quantities of carbohydrate-rich food (Abraham et al., 2016), animal forage, fibre production, construction materials, as ornamental (Hölscher and Schneider, 1998). Moreover, products from enset are used in different forms in traditional medicine and a starch for textile, adhesive and paper industries is being produced (Diro and van Staden, 2005; Temesgen et al., 2014).

The present cultivated enset in Ethiopia originated from few wild progenitors. However, enset has a mixed mode of reproduction in which, the wild enset reproduces sexually through seeds, while cultivated enset is generally propagated vegetatively. Naturally, vegetative propagation results in the genetic fixation, which could lead to loss of clones owing to diseases, and abiotic stress resistant due to selection pressures, or changes in land use systems. The wild Musaceae family have always been known for their broad genetic base and carry several desirable genes (Vuylsteke et al., 1995) which breeders should look in future. Seed propagation of 
enset might be one of the options to create variation and allow breeders to select the clones with desired traits with the knowledge of enset seed germination and seedling growing techniques to breed enset efficiently (Karlsson et al., 2012). So far, maintenance of the existing germplasm in the wild populations, as well as introduction of genes from wild or related species into the cultivated clones is useful to improve e.g. disease resistance and adaptation could have a major impact on future food security of Ethiopia.

Genetic diversity study on available genotypes either from molecular and phenotypic data may help to understand the extent of the variation in the species (Biswas, et al., 2020). The source of variation in enset crop lacks to pin point either due to cross pollination (recombination) or entirely due to ancestors' inherent genetic makeup. The information generated from such researches explain the variation is due to the individual genetic constitutes which can help the breeders to design exploitation of genetic diversity in the species as a whole but not able to provide information how much is the breeder can create variation. Unlike to most vegetatively propagated species that are known to be polyploidy in nature and have homogenous plants in their clones with heterozygous loci in their genome, little is known about the genetic structure of the diploid species of E, ventricosum that produces morphologically uniform/ homogenous plants when multiplied by vegetative propagation.

The improvement of cross pollinated crops exploits the variation within and between the family that can be manipulated by planned hybridization or recombination breeding. However, before suggesting the possibility of applying recombination breeding to exploit the within and between families variation, it is necessary to 
4

understand the extent of phenotypic variation inherited to the progenies since, the extent of variation within a seed cohort is not known. Morphological comparisons of genotypes within seed cohorts can help much to understand the extent of genetic variation achieved through seed propagation. Generating such information is needed to launch crossing program and selection of clones from natural outcrosses to develop new enset cultivars. Hence, the present studies has undertaken detailed morphological characterization on the progenies of each mother plant with the objectives of determining the number and types of qualitative morphological traits, and estimate the variability parameters for quantitative traits present among the enset genotypes.

\section{MATERIALS AND METHODS}

\section{Description of the Study Area}

The study was conducted in Wolaita Sodo University field research station located in Wolaita Sodo town, Wolaita Zone, SNNPR region $315 \mathrm{~km}$ away from Addis Ababa. The specific location of the experimental area lies at elevation of 1891 meter above sea level and its geographic coordinates are $37^{0} 45^{\prime} 08^{\prime \prime} \mathrm{E}$ longitudes and $6^{0} 50^{\prime} 00^{\prime \prime} \mathrm{N}$ latitude. Wolaita Zone covers an altitude range of 800 to 3500 meter above sea level. The area experiences bimodal type of rainfall. The shortest rainy season stretches from March to April and the main rainy season extends from June to September. The 12 years average annual rainfall data (2003 to 2015 cropping years) was $1580 \mathrm{~mm}$. Minimum and maximum average annual temperature was $12.7^{\circ} \mathrm{C}$ and $23.7^{\circ} \mathrm{C}$ respectively and major soil type of the area was reported to be Nitosols (Fanuel et al., 2017) having well drained sandy loam textural class with low organic carbon content (Hailu et al., 2017).

\section{Plant Material}

Progenies of the mother plants of clonal landraces of enset cultivated in Wolaita zone and wild plants of enset genotypes collected from natural forests found in Dawuro 
and Keffae areas were used for this study. The enset collections used for this study were constituted from six commonly cultivated landraces and four wild plants of enset genotypes (Appendix Table 1). The progenies of each clone were generated from the seeds of the respective mother plant.

\section{Design and Layout of the Field Experiment}

Each of the progenies of the mother plants (the 10 clones) was planted in a single row of 16 plants using nested design. The spacing was $3 \mathrm{~m}$ between plants and $4 \mathrm{~m}$ between rows. All the management practices such as weeding, hoeing, mulching, watering and fertilizer application were properly and uniformly applied to all plots using the recommended practices of Areka Agricultural Research Center.

\section{Data Collection}

The data included both qualitative and quantitative parameters. Data for qualitative parameters were collected from all available plants in each plot. While for the quantitative parameters data were collected from four plants per plot. List of qualitative and quantitative parameters are depicted in Appendix Table 2.

\section{Data Analysis}

Chi-squared analyses were conducted to test the goodness of fit of the observed segregation to the theoretically expected ratios for a given genetic model to determine the number of genes involved in the inheritance of the qualitative characters.

The formula for calculating chi-square analysis $\left(\chi^{2}\right)$ is described below:

$$
\chi^{2}=\sum \frac{(O-E)^{2}}{E}
$$

Where, $\Sigma$ is summation of the chi-squared values of the alleles, $\mathrm{O}$ is observed values and $\mathrm{E}$ is expected values.

For a recombinant inbred (RI) population a 1:1 ratio is expected for a single gene. However for an $\mathrm{F}_{2}$ ( $2^{\text {nd }}$ filial generation) population a single dominant gene is expected in a 3:1 ratio, and for a co-dominant single gene the expected genetic ratio will be 1:2:1.

Analysis of variance was computed using nested design for each quantitative character in order to estimate the variability among accessions for each 
6

trait. Hierarchical classification was used for the partitioning of the variation into different sources of variations (Table 3). The ANOVA was constructed by considering the experimental units (the four enset plants within each clone) as factor B nested within levels of factor A (the 10 clones) (Sokal and Rolf, 1969). The differences between treatment means was compared using least significant difference (LSD) test at 5\% level of significance when the ANOVA showed the presence of significant difference between genotypes.

Table 3 Form of ANOVA table for nested design

Source of variation Degree of freedom

Between accessions (Factor A)

Within accessions $(\mathrm{B}(\mathrm{A})=$ error $)$

Total

$a=$ number of germplasm accessions, $b=$ number of sample plants per germplasm accession

\section{Variability Analysis}

The phenotypic and genotypic variances of agronomic traits at each location were estimated using the following formula described by Burton and Devane (1953);

$$
\sigma_{g}^{2}=\frac{M S g-M S e}{r}
$$

Where, $\sigma_{g}^{2}=$ genetic variance.

$\mathrm{MSg}=$ mean square due to genotypes.

MSe $=$ environmental variance (error mean square) 


$$
\begin{aligned}
& \mathrm{r}=\text { number of replications } \\
& \sigma_{p}^{2}=\sigma_{g}^{2}+\mathrm{MSe}=\text { phenotypic variable, and }
\end{aligned}
$$

A coefficient of variations at phenotypic and genotypic levels was estimated with the following formula.

$$
\begin{aligned}
& \mathrm{PCV}=\frac{\sqrt{\text { phenotypic variance }}}{\text { population mean for character }} \times 100 \\
& \mathrm{GCV}=\frac{\sqrt{\text { genotypic variance }}}{\text { population mean for character }} \times 100
\end{aligned}
$$

\section{Estimation of heritability in broad-sense $\left(h^{2}\right)$ and genetic advance (GA)}

Broad-sense heritability $\left(\boldsymbol{h}^{2}\right)$ : was calculated as the ratio of the genotypic variance to the phenotypic variance, using the following formula described by Allard (1960);

$$
h^{2}=\frac{\sigma_{g}^{2}}{\sigma_{p}^{2}} \times 100
$$

Where, $\quad h^{2}=$ heritability (in broad-sense)

$$
\begin{gathered}
\sigma_{g}^{2}=\text { genotypic variance } \\
\sigma_{p}^{2}=\text { phenotypic variance }
\end{gathered}
$$

Genetic advance $(\boldsymbol{G A})$ : was computed using the formula adopted from Johnson et al. (1955) and Allard (1960):

$$
\text { Genetic advance: GA5\% }=(\mathrm{k})\left(\sigma_{\mathrm{p}}\right) \times\left(\mathrm{h}_{\mathrm{b}}^{2}\right)
$$

Where: $-\mathrm{GA}=$ genetic advance at $5 \%$ selection intensity, $\mathrm{K}=$ the selection intensity ( $\mathrm{K}=2.06$ at $5 \%$ selection intensity), $\sigma_{\mathrm{p}}$ is the phenotypic standard deviation and $\mathrm{h}^{2} \mathrm{~b}$ is heritability in broad sense.

Genetic advance as percent of mean: GAM5\% $=\frac{G A}{X} x 100$

Where: - GAM5\%=Genetic advance as percent of mean at 5\% selection intensity, $\mathrm{GA}=$ genetic advance, and $\mathrm{X}=$ mean value of the trait. 
8

\section{RESULTS}

\section{Variation for Qualitative Morphological Traits}

Enset plant is usually propagated vegetatively through corms. Plants propagated through corms are genetically uniform, hence they are said to be clones. However, most asexually (vegetatively) reproducing plants when propagated through seeds (sexually) their progenies show genetically diverse genotypes. Similarly, the enset progenies considered in this study demonstrated genetic diversity in both qualitative and quantitative traits as they were propagated through seeds obtained from each of the ten mother plants. The data for all four qualitative traits showed single gene segregation confirmed by chi-squared analysis for single gene (non-significant for $\chi^{2}$ $<3.841$ at $\mathrm{P}=0.05$ and 1 d.f.) at $\mathrm{F}_{2}$ generation with genetic ratio $=3: 1$ for the eight landraces (Appendix tables 1, 2, 3, 4). On the other hand the cultivated landrace Gefetanuwa-1 didn't show segregation for all qualitative traits, while Gefetanuwa-2 segregated for a single gene with genetic ratio of recombinant inbred lines $(1: 1$ at $\mathrm{P}=$ 0.05 and 1 d.f.) (Table 4). The three qualitative traits; pseudostem color, petiole color and mid-rib color exhibited segregation for two distinct types of color classes for each trait (Table 4). However, leaf color showed segregation only in three progenies of the landrace cultivars (Banga, Gefetanuwa-1, and GamoGofa71), while the rest seven landrace progenies exhibited deep green leaf color with no segregation. The wild landrace Erpha15 (wild 15) segregated monogenically (3 deep green: 1 light red) only for pseudostem color, while petiole color, mid-rib color and leaf color did not show segregation and all the progenies showed greenish brown, light red and deep green colors, respectively. 
Table 4 summary of the segregation of enset clones for different colors observed in the four morphological traits

\begin{tabular}{|c|c|c|c|c|}
\hline Enset clones & Pseudostem color & Petiole color & Midrib color & Leaf color \\
\hline Arkia & $\begin{array}{l}3 \text { green:1 dark- } \\
\text { red }\end{array}$ & $\begin{array}{l}1 \text { light-green: } 3 \\
\text { red-purple }\end{array}$ & $\begin{array}{l}1 \text { light-green:3 } \\
\text { red }\end{array}$ & $\begin{array}{l}1 \text { light-green: } \\
3 \text { deep-green }\end{array}$ \\
\hline Banga & $\begin{array}{l}3 \text { dark-red: } 1 \\
\text { green-black }\end{array}$ & $\begin{array}{l}1 \text { light-green: } 3 \\
\text { dark-red }\end{array}$ & $\begin{array}{l}1 \text { light-green: } 3 \\
\text { brown-red }\end{array}$ & $\begin{array}{l}1 \text { light-green: } \\
3 \text { dark-green }\end{array}$ \\
\hline Gefetanua-2 & $\begin{array}{l}1 \text { light-green: } 1 \\
\text { reddish-brown }\end{array}$ & $\begin{array}{l}1 \text { light-green: } 1 \\
\text { green-red }\end{array}$ & $\begin{array}{l}1 \text { light-green: } 1 \\
\text { greenish-brown }\end{array}$ & $\begin{array}{l}1 \text { light-green: } \\
1 \text { deep-green }\end{array}$ \\
\hline Wild 15 & $\begin{array}{l}3 \text { deep-green: } 1 \\
\text { light-red }\end{array}$ & $\begin{array}{l}\text { All greenish } \\
\text { brown }\end{array}$ & All light-red & $\begin{array}{l}\text { All deep- } \\
\text { green }\end{array}$ \\
\hline Alageena & All red & All brown-red & All red & $\begin{array}{l}\text { All deep- } \\
\text { green }\end{array}$ \\
\hline Wild 9 & $\begin{array}{l}3 \text { green: } 1 \text { dark- } \\
\text { red }\end{array}$ & $\begin{array}{l}1 \text { red:3 dark- } \\
\text { brown }\end{array}$ & $\begin{array}{l}1 \text { light-red:3 } \\
\text { dark-brown }\end{array}$ & $\begin{array}{l}\text { All deep- } \\
\text { green }\end{array}$ \\
\hline Gefetanua-1 & $\begin{array}{l}1 \text { light-green:3 } \\
\text { red }\end{array}$ & $\begin{array}{l}1 \text { light-green: } 3 \\
\text { greenish-red }\end{array}$ & $\begin{array}{l}1 \text { light-green: } 3 \\
\text { red-brown }\end{array}$ & $\begin{array}{l}1 \text { light-green: } \\
1 \text { deep-green }\end{array}$ \\
\hline Wild 11 & $\begin{array}{l}1 \text { deep-green: } 3 \\
\text { red-green }\end{array}$ & $\begin{array}{l}1 \text { light-red: } 3 \\
\text { greenish-red }\end{array}$ & $\begin{array}{l}1 \text { light-red: } \\
3 \text { dark brown }\end{array}$ & $\begin{array}{l}\text { All deep- } \\
\text { green }\end{array}$ \\
\hline Wild 10 & $\begin{array}{l}1 \text { light-green: } 3 \\
\text { dark-red }\end{array}$ & $\begin{array}{l}1 \text { purple: } 3 \\
\text { greenish-red }\end{array}$ & $\begin{array}{l}3 \text { light red:1 dark } \\
\text { brown }\end{array}$ & $\begin{array}{l}\text { All deep- } \\
\text { green }\end{array}$ \\
\hline Gamogofa 71 & $\begin{array}{l}1 \text { light-green:3 } \\
\text { red }\end{array}$ & $\begin{array}{l}1 \text { light-green: } 3 \\
\text { red green }\end{array}$ & 1 green: 3 red & $\begin{array}{l}1 \text { light-green: } \\
3 \text { deep-green }\end{array}$ \\
\hline
\end{tabular}

\section{Variation for Quantitative Morphological Traits}

\section{Analyses of Variances}

Univariate analysis of variance computed for the quantitative agronomic traits showed significant differences $(\mathrm{P}<0.05)$ among the enset genotypes except for pseudostem length that displayed non-significant mean square for genotypes (Table 5). This study demonstrated the presence of significant variation among the genotypes for the agronomic traits that witnessed progress/improvement can be made for the traits considered through selection and breeding efforts. Leaf length exhibited presence of highly significant $(\mathrm{P}<0.01)$ difference between the genotypes (Table 5) indicating that this trait is the most varied among the quantitative traits. 
10

Table 5: Mean squares for the different sources of variation and their corresponding $\mathrm{CV}$ for the six quantitative traits of 10 enset genotypes tested at Wolaita Sodo University

\begin{tabular}{lllll} 
Traits & $\begin{array}{l}\text { Replications } \\
(\mathrm{Df}=3)\end{array}$ & $\begin{array}{l}\text { Treatments } \\
(\mathrm{Df}=9)\end{array}$ & $\begin{array}{l}\text { Error } \\
(\mathrm{Df}=27)\end{array}$ & $\begin{array}{l}\mathrm{CV} \\
(\%)\end{array}$ \\
\hline Leaf length (LL) & 11923 & $13234^{* *}$ & 3789 & 17.9 \\
Leaf width (LW) & 170.9 & $423.4^{*}$ & 164.8 & 18.2 \\
Number of leaves (NL) & 10.445 & $18.10^{*}$ & 7.405 & 22.6 \\
Plant height (PH) & 31444 & $29588^{*}$ & 10672 & 19.3 \\
Pseudostem & 427.2 & $1431.7^{*}$ & 454.2 & 27.3 \\
circumference (PSC) & & & & \\
Pseudostem length (PSL) & 6519 & $4368^{\mathrm{ns}}$ & 2206 & 24.6 \\
\hline
\end{tabular}

*Significant at $\mathrm{p}=0.05, * *$ Highly significant at $\mathrm{p}=0.01$, Df: Degree of freedom, CV (\%): Coefficient of variation, ns: Non-significant

\section{Mean Performance of Genotypes}

Estimated mean performances of the 10 enset genotypes for the sixth agronomic morphological traits are presented in Table 6. The result showed presence of significant differences for five of the traits viz. leaf length, leaf width, number of leaves, plant height, and pseudostem circumference at $5 \%$ probability level that further confirmed by mean comparison tests using the respective LSD values. The mean data indicated that mainly the wild genotypes had inferior performances compared to the cultivated clonal landraces with the exception of the genotype 'Wild $15^{\prime}$ that showed average or competitive performance in all the traits evaluated (Table 6). The genotype 'Wild 15' performed better than 'Alageena' and 'Gamo Gofa71' clones for majority of agronomic traits and also ranked second next to 'Arkia' for traits such as leaf width, number of leaves, pseudostem length and plant height. The cultivated clonal landrace 'Arkia' is the top performer for majority of traits except for pseudostem length on which 'Wild 15' was the top performer, whereas 'Wild 11' 
was the least (Table 6). The enset genotypes showed unique performances with respect to pseudostem length though statistically not significant; for instance, the least performing genotypes 'Wild 11 and Wild 10' performed better than the cultivated ones 'Alageena and Gamo Gofa71' suggesting that the wild enset genotypes can also contribute to the improvement of kocho yield apart from quality traits and stress resistance.

Table 6: Mean performance of the 10 enset genotypes and their studied traits tested at Wolaita Sodo University

\begin{tabular}{llllllll} 
Entries & Genotypes & LL & LW & NL & PH & PSC & PSL \\
\hline 1 & Wild 11 & $276.3^{\mathrm{a}}$ & $54.23^{\mathrm{a}}$ & $9.67^{\mathrm{a}}$ & $445^{\mathrm{a}}$ & $48.38^{\mathrm{a}}$ & 168.8 \\
2 & Wild 10 & $282.8^{\mathrm{a}}$ & $64.35^{\mathrm{ab}}$ & $9.90^{\mathrm{a}}$ & $451.8^{\mathrm{a}}$ & $59.63^{\mathrm{ab}}$ & 169.0 \\
3 & Wild 9 & $317^{\mathrm{abc}}$ & $71.78^{\mathrm{abc}}$ & $10.35^{\mathrm{a}}$ & $533^{\mathrm{ab}}$ & $80.55^{\mathrm{b}}$ & 216.0 \\
4 & Wild 15 & $391.9^{\mathrm{cd}}$ & $80.03^{\mathrm{bc}}$ & $12.92^{\mathrm{ab}}$ & $631.1^{\mathrm{b}}$ & $76.45^{\mathrm{ab}}$ & 239.2 \\
5 & Alageena & $292^{\mathrm{ab}}$ & $58.58^{\mathrm{a}}$ & $10.45^{\mathrm{a}}$ & $447.7^{\mathrm{a}}$ & $63.25^{\mathrm{ab}}$ & 155.7 \\
6 & Gamo Gofa 71 & $303.9^{\mathrm{abc}}$ & $69.58^{\mathrm{ab}}$ & $12.10^{\mathrm{a}}$ & $449.6^{\mathrm{a}}$ & $82.23^{\mathrm{b}}$ & 145.8 \\
7 & Banga & $348.9^{\mathrm{abcd}}$ & $67.50^{\mathrm{ab}}$ & $12.30^{\mathrm{a}}$ & $534.9^{\mathrm{ab}}$ & $81.0^{\mathrm{b}}$ & 186.0 \\
8 & Gefetanuwa 1 & $374.5^{\mathrm{bcd}}$ & $70.95^{\mathrm{abc}}$ & $13.2^{\mathrm{ab}}$ & $557.7^{\mathrm{ab}}$ & $81.68^{\mathrm{b}}$ & 183.2 \\
9 & Gefetanuwa & $411.9^{\mathrm{d}}$ & $78.90^{\mathrm{bc}}$ & $12.6^{\mathrm{a}}$ & $622.8^{\mathrm{b}}$ & $89.1 \mathrm{~b}^{\mathrm{c}}$ & 210.9 \\
10 & Arkia & $436.5^{\mathrm{d}}$ & $88.80^{\mathrm{c}}$ & $16.8^{\mathrm{b}}$ & $673.5^{\mathrm{b}}$ & $118.2^{\mathrm{c}}$ & 237.0 \\
\hline \multicolumn{7}{l}{ Means followed by the same letter are not significantly different $(\mathrm{p}=0.05)$. LL= leaf length, LW= } \\
leaf width, NL= number of leaves, PH= plant height, PSC= pseudostem circumference, PSL= \\
pseudostem length
\end{tabular}

\section{Estimates of Variance Components}

The results of estimated variance components, phenotypic (PCV) and genotypic (GCV) coefficients of variation, broad sense heritability $\left(\mathrm{h}_{\mathrm{b}}{ }^{2}\right)$, genetic advance (GA) and genetic advance as percentage of mean (GAM\%) were calculated for the six traits investigated using the ANOVA computed between the tested genotypes and presented in Table 7. 
12

\section{Phenotypic and Genotypic Coefficients of Variation}

Both the PCV and GCV values computed for the six traits ranged from 21.49 to 33.88 and 11.40 to 20.04 for leaf width and pseudostem circumference, respectively (Table 7). The value of phenotypic coefficients of variation were generally higher than the corresponding value of genotypic coefficients of variation for all traits studied indicating the influence of environmental differences occurred across years was significant, particularly annual climatic (weather) changes were important. High PCV was observed along with moderate GCV values for all the six traits studied.

\section{Heritability in Broad Sense}

Broad sense heritability $\left(h_{b}^{2}\right)$, which is an estimate of the total contribution of the genetic variance to the total phenotypic variance ranged from 0.197 (pseudostem length) to 0.38 (leaf length). The heritability value estimated was moderate for half of the traits; namely, leaf length, plant height and pseudostem circumference which might be due to presence of relatively higher genotypic variations among the enset genotypes and less effect of environmental influence on the expression of these traits. The remaining three traits leaf width, number of leaves per plant and pseudostem length exhibited low estimate of heritability (Table 7) implying the environmental influence in the expression of these traits was higher as compared to the genetic variation between the genotypes.

\section{Genetic Advance}

The genetic advance percent of means (GAM) expressed ranged from $11.11 \%$ for leaf length to $24.42 \%$ for pseudostem circumference. This refers to the improvement 
of the characters in genotypic value for the new population compared with the base population in one cycle of selection is within the range of $11.11 \%$ to $24.42 \%$ at $5 \%$ selection intensity. High GAM was observed for pseudostem circumference (24.42\%) whereas moderate GAM was obtained for the rest of the traits that showed there is huge potential for improving the enset yield through selection and breeding using the available germplasm (Table 7).

Table 7: Estimates of variability parameters for six traits of the 10 enset genotypes tested at Wolaita Sodo University in 2020 crop year

\begin{tabular}{llllllllll} 
Traits & Mean & $\sigma^{2} \mathrm{~g}$ & $\sigma_{\mathrm{p}}^{2}$ & $\sigma^{2}$ & $\mathrm{GCV}$ & $\mathrm{PCV}$ & $\mathrm{h}_{\mathrm{b}}^{2}$ & GA5\% & GAM5\% \\
\hline LL & 343.6 & 2361.25 & 6150.3 & 3789 & 14.14 & 22.82 & 38.34 & 62.02 & 18.05 \\
LW & 70.5 & 64.65 & 229.45 & 164.8 & 11.40 & 21.49 & 28.18 & 8.79 & 12.47 \\
NL & 12.03 & 2.67 & 10.08 & 7.41 & 13.59 & 26.39 & 26.53 & 1.735 & 14.42 \\
PH & 535 & 4729 & 15401 & 10672 & 12.85 & 23.20 & 30.71 & 78.50 & 14.67 \\
PSC & 78 & 244.38 & 698.58 & 454.2 & 20.04 & 33.88 & 34.98 & 19.05 & 24.42 \\
PSL & 191.1 & 540.5 & 2746.5 & 2206 & 12.17 & 27.42 & 19.67 & 21.24 & 11.11
\end{tabular}

N.B. $\sigma 2 \mathrm{~g}=$ genetic variance, $\sigma 2 \mathrm{p}=$ phenotypic variance, $\sigma 2 \mathrm{e}=$ environmental variance, $\mathrm{GCV}=$ genotypic coefficient of variance, $\mathrm{PCV}=$ phenotypic coefficient of variance, $\mathrm{h} 2 \mathrm{~b}=$ heritability in broad sense, GA5\% = genetic advance at 5\% selection intensity, and GAM5\% = genetic advance as percentage of the mean at $5 \%$ selection intensity

\section{DISCUSSION}

Enset is a perennial crop mainly cultivated in the highlands of southern and southwestern parts of Ethiopia, particularly in densely populated areas of the country (Yemataw, et al., 2014) such as, Gurage, Silte, Wolaita, Gedeo, Sidama and Gamo Gofa zones. It is a staple food for nearly one-fifth of the country's population. The crop represents $65 \%$ of the total crop production in the southern regions of Ethiopia. The major food types produced from matured enset plant are Kocho, bulla and amicho. Kocho is fermented starch processed from scraped leaf sheaths and corms; it 
14

constitutes the major product of enset. Several food recipes can be prepared from this product depending on the cultures; kitta (leavened bread), burseme, kocho frfir, etc. Bulla is a liquid, which, is obtained when leaf sheaths and corms are pulverized; the liquid starch is dried to make white powder, Bulla is usually used to make porridge. Amicho is prepared from pieces of corm/rhizomes of enset plant and boiled and eaten similar to the other root crops (Brandt, et al., 1997). The byproducts of enset can be used for fiber production that can be further processed to make different products; bags, ropes, twines, cordage, and mat.

Though enset has several benefits to the society little progress has been made in terms of improving the crop through selection and breeding works to develop improved cultivars. So far only six cultivars (Zerietta (Ashura), Mesena (Eskuris), Kelisa (Wellanchie), Endale (Manduluka), Yanbule (Digomerza) and Gewada (Henuwa)) were released by Areka Agricultural research center. The released cultivars were developed by clonal selections method by screening from available collections (cultivated clonal landraces) obtained from farmers' of the region.

Since enset is a flowering plant that can be able to produce viable seeds, it is possible to develop cultivars through hybridization and selection methods. It is known that the genetic structures of cross-pollinated and vegetatively propagated plant species are highly heterozygous in nature. Hence, it is possible to generate a variable base population up on selfing a clonal variety. Cultivated landraces of enset clones are propagated vegetatively through corms/suckers whereas wild enset plants are disseminated through seeds (Birmeta, et al., 2004). Hence, wild plants of enset plant could be in different/various filial generations (F1, F2, F3, etc.) since they are propagated through seeds; furthermore, enset plant is by nature a cross-pollinated 
plant as well as capable of multiplying through vegetative means. In the current study cultivated clonal plants and wild enset plants were used to study the genetic structures of the genotypes. The findings of our study indicated that progenies of clonal landrace cultivar “Gefetanuwa 2' segregated with 1:1 genetic ratio for a single gene for the qualitative traits; viz a viz, pseudostem, midrib, petiole and leaf colors. Therefore, the result justified that the mother plant 'Gefetanuwa 2' was different from F1 that could be either F4 or F5 plant. While the other cultivated clonal landrace "Gefetanua 1" didn't show segregation for all progenies of the mother plant implying this clone could be a selection from recombinant inbred lines. The wild plant selection 'Wild15 (Erpha)' segregated monogenically with genetic ratio of 3:1 only for PSC, while it didn't segregate for the rest 3 qualitative traits. On the other hand, the cultivated clonal cultivars segregated monogenically with a 3:1 genetic ratio confirming the mother plants were an F1 (first filial) generation. Progenies of the enset genotypes showed differences in the diversity of colors for the qualitative morphological traits (PSC, PC, MC and LC). Petiole color (PC) and midrib colors (MC) each exhibited 10 different types of colors; the pseudostem (PSC) showed 8 different types of colors while the leaf color exhibited only 3 types of colors. Compared to the mother plants which had $5-6$ phenotypes, the $3-4$ additional phenotypes were displayed in the progenies for the qualitative traits except leaf color.

The progenies of the mother plants also demonstrated the potential for creating huge diversity for establishing a base population in the F2 for quantitative (breeding) traits following selfing of the clones of both the cultivated and wild genotypes. The progenies of the 10 enset genotypes differed significantly for five of the six metric (quantitative) traits except pseudostem length. Generally the cultivated 
clones performed better than the wild types; however, one of the wild types (Wild 15) showed outstanding performance for majority of the traits following the cultivated cultivar 'Arkia' that excelled all the rest. The variance components computed for the five traits showed presence of higher level of variations among the genotypes that could be enough to improve the yield and other desirable traits through selection. The PCV and GCV values for the traits fall in the range of moderate to high level of variation as indicated by Deshmukh et al. (1986) where, the GCV and PCV values were considered low if it is $(<10 \%)$, moderate (10 to $20 \%$ ) and high (>20\%). The relatively higher values of PCV compared to the respective values of GCV indicate the influence of environmental variation in the performance of the traits that is common for metric/ yield traits as they are usually constituted from many genes with minor effects and additive in nature.

The estimated values of broad-sense heritability and the respective genetic advance indicated that it is possible to improve the enset yield and other associated traits through selection. According to Dabholkar (1992), moderate values of heritability were scored for majority of enset yield traits followed by high values of genetic advance as percent of the mean value of each trait. High values of genetic advance indicate the involvement of additive gene action in the genetic make-up of the quantitative traits. Johnson et al. (1955) reported that heritability estimates along with genetic gain would be more satisfying than heritability solitary in predicting the consequential effect of selection to choose the best individual plant. Hence, this study demonstrated that it is possible to create genetic variation through selfing of the existing clones of the farmers' cultivated enset landraces as well as wild types for qualitative and quantitative traits of interest and make improvements or develop new 
cultivars either through selection or crossing the elite types and evaluate the F1s and release the best performing novel clones to farmers.

\section{CONCLUSIONS}

Enset is one of the major staple food sources for Ethiopian population. It is a highly resilient crop with regard to environmental stresses such as drought and frost. However, little attention has been given in terms of improving the productivity of the crop mainly due to its local importance and perennial nature of the crop. So far only six improved cultivars have been released to growers. This study gave insight that there is huge potential to improve this crop through hybridization and clonal selection methods since enset has viable flowers and can easily propagated either through seeds or vegetatively with its corm. Heterosis or hybrid vigour can be fixed once we develop superior gene combinations through crosses of elite enset clones. We can also create genetic variability through selfing of the various clonal landrace collections that can be used as sources of genes for quality and yield improvement as well as stress (both biotic and abiotic) tolerance.

\section{Data Availability}

The data used to support the findings of this study are presented in the manuscript. Additional data can be obtained from the corresponding author upon request

\section{Acknowledgements}

The authors thank Wolaita Sodo University for maintaining the germplasm in its research farm plots. We thank technical staff members of the department of horticulture, college of agriculture.

\section{Funding Statement}


18

The cost of establishment and maintenance of the enset farm was financed by

Wolaita Sodo University research and community service directorate.

\section{Conflict of Interest}

The authors declared there is no conflict of interest for authorship of this manuscript

\section{REFERENCES}

Allard, R.W. 1960. Principles of Plant Breeding. John Willey and Sons, Inc., New York, USA.

Bezuneh,T., Feleke, A., Beyie, R., 1967. The cultivation of genus Ensete in Ethiopia. Soil and Crops Science Society of Florida 27,133-141.

Biswas, M.K., et al., 2020. The landscape of microsatellites in the enset (Ensete ventricosum) genome and web_based marker resource development. Scientic Reports in press,. http://doi.org/10.1038/s41598-020-71984-X

Birmeta, G., Nybom, H. and Bekele, E. 2004. Distinction between wild and cultivated enset (Ensete ventricosum) gene pools in Ethiopia using RAPD markers. Hereditas 140:139-148.

Borrell, J.S., Biswas, M.K. Goodwin, M. lomme, G. B, Schwarzacher, T. HeslopHarrison, P.J.S. ..., P. Wilkin. 2019. Enset in Ethiopia: A poorly characterized but resilient starch staple. Annals of Botany, 123 (5). pp. 747766, $10.1093 / \mathrm{aob} / \mathrm{mcy} 214$

Bosha A., Dalbato A.L., Tana T., Mohammed W., Tesfaye B., Karlsson L.M., 2016. Nutritional and chemical properties of fermented food of wild and cultivated genotypes of enset (Ensete ventricosum). Food Res. Int. 89, 806-811.

Brandt, A.S ., Anita, S., Hiebsch, C , McCabe, J. T., Endale, T., Mulugeta, D., Gizachew, W-M., Gebre,Y, Masayoshi, S. and Shiferaw, T., 1997. The "Tree against Hunger" Enset based agricultural systems in Ethiopia. Washington DC: American Association for the Advancement of Science. 
Burton, G.A. and Devane, E.H.1953. Estimation of heritability in tall festca (Festuca arundinacea) from replicated clonal materials. Agronomy J. 45:478-479.

Dabholkar. 1992. Elements of biometrical Genetics. Concept Publishing Company, New Delhi.

Deshmukh SN, Basu MS, Reddy PS .1986. Genetic variability, character association and path coefficients of quantitative traits in Virginia bunch varieties of groundnut. Ind. J. Agric. Sci. 56:515-518.

Diro M, van Staden J,, Bornman CH. 2003. In vitro regeneration of Ensete ventricosum from zygotic embryos of stored seeds. South African Journal of Botany 69: 364-369

Diro M, van Staden VJ., 2005. The type of explants plays a determining role in the micro propagation of Ensete ventricosum. SA J. Bot. 71: 154-159.

George Jacob., 2004. "Enset- The "false banana" as food security", Ethiopia.

Hailu Gebru, Ali Mohammed, Nigussie Dechassa and Derbew Belew, 2017. Profitability of potato (Solanum tuberosum L.) as affected by NP nutrition and variety in Southern Ethiopia. Vol. 9(2), pp. 9-16

Holscher, D. and Schneider, B., 1998. Phenylphenalenones from Enset Ventricomsum. Elsevier Science, Phytochemistry49. (7), 2155-2157.

James Rohlf and Robert R. Sokal. 1969. Statistical Tables. 5 illus. Folkestone: W. H. Freeman and Company Ltd. 253 pp., 64 s (cloth) 24 s (paper)

Johnson, HW, Robinson, HF Comstock, RE. 1955. Estimation of genetic and environmental variability in soybeans. Agronomy J. 47: 314-318.

Karlsson, L.M., Tamado, T., Dalbato, A.L. and Mikias, Y. 2012. Sexual and asexual reproduction of enset as tools to increase agro-biodiversity and agricultural productivity, p 38. In: Workeneh S, Dechassa N, Zewdu T, Bekele H (Eds) Book of Abstracts of the International Conference on Biodiversity Conservation and Ecosystems Services for Climate Change Mitigation and Sustainable Development. UNDP and Haramaya University, Ethiopia, December 20-22, 2012.

Pursglove, J.W., 1972. Tropical Crops: Monocotylodons. Holsted press, a division of John Wiley and Sons, Inc. New York, Pp.243-244. 
20

Robert R. Sokal and F. James Rohlf. 1969. Biometry, The Principles and Practice of Statistics in Biological Research. 89 illus., 56 tab. Folkestone: W. H. Freeman and Company Ltd. 776 pp., 126 s. F.

Simmonds, N. W., 1962. The evolution of the bananas. Butler and Tanner Ltd. London.

Olango M. T, Bizuayehu T., Marcello Catellani and Mario Enrico Pè., 2014. Indigenous knowledge, use and on-farm management of enset (Ensete ventricosum (Welw.) Cheesman) diversity in Wolaita, Southern Ethiopia

Vavilov, N. I., Rodin, L. E., 1997. Five continents. International Plant Genetic Resource Institute, Rome, Italy.198pp.

Vuylsteke D, Ortiz R, Ferris S, Swennen R 1995.'PITA-9’: A black sigatoka resistant hybrid from the 'False Horn' plantain gene pool. Hortscience 30395-397.

Yemataw , Z, Chala A, Ambachew D, Studholme D, Grant M, Tesfaye K (2017) Morphological variation and inter-relationships of quantitative traits in enset (Ensete ventricosum (Welw.) Cheesman) germplasm from south and southwestern Ethiopia. Plants 6:56 


\section{Appendix}

Appendix Table 1 Description of the enset genotypes used in the study

\begin{tabular}{|c|c|c|c|c|c|c|c|}
\hline $\begin{array}{l}\text { Ser. } \\
\text { no }\end{array}$ & clones & $\begin{array}{l}\text { Collection } \\
\text { site/location }\end{array}$ & $\begin{array}{l}\text { Altitude } \\
\text { of area }\end{array}$ & $\begin{array}{l}\text { Geographical } \\
\text { Location }\end{array}$ & $\begin{array}{l}\text { Av. annual } \\
\text { temperature }\end{array}$ & $\begin{array}{l}\text { Av. } \\
\text { annual } \\
\text { RF }\end{array}$ & $\begin{array}{l}\text { Soil } \\
\text { type } \\
\text { of the } \\
\text { area }\end{array}$ \\
\hline 1 & Arkiya & Sodo Zuria & 1924 & $\begin{array}{l}06^{0} 53^{\prime} 36.3^{\prime \prime} \mathrm{N} \\
37^{0} 43^{\prime} 36.9^{\prime \prime} \mathrm{E}\end{array}$ & $22^{0}$ & 1340 & Clay \\
\hline 2 & Banga & Sodo Zuria & 1920 & $\begin{array}{l}06^{0} 53^{\prime} 32.0^{\prime \prime} \mathrm{N} \\
37^{0} 43^{\prime} 30.1^{\prime \prime} \mathrm{E}\end{array}$ & $21^{0}$ & 1340 & Clay \\
\hline 3 & $\begin{array}{l}\text { Gefetanua } \\
2\end{array}$ & Sodo Zuria & 1912 & $\begin{array}{l}06^{0} 53^{\prime} 32.4^{\prime \prime} \mathrm{N} \\
37^{0} 43^{\prime} 34.7^{\prime \prime} \mathrm{E}\end{array}$ & $20^{\circ}$ & 1340 & Clay \\
\hline 4 & Wild15 & Waka & 2369 & $\begin{array}{l}07^{0} 03^{\prime} 33.2^{\prime \prime} \mathrm{N} \\
37^{0} 0.9^{\prime} 59.8^{\prime \prime} \mathrm{E}\end{array}$ & $26^{0}$ & 1500 & $\begin{array}{l}\text { Silt } \\
\text { loam }\end{array}$ \\
\hline 5 & Alageena & Sodo Zuria & 1924 & $\begin{array}{l}06^{0} 53^{\prime} 25.1^{\prime \prime} \mathrm{N} \\
37^{0} 43^{\prime} 38.7^{\prime \prime} \mathrm{E}\end{array}$ & $22^{0}$ & 1340 & Clay \\
\hline 6 & *Wild 9 & WSU & 1886 & $\begin{array}{l}06^{0} 49^{\prime} 55.4^{\prime \prime} \mathrm{N} \\
37^{0} 45^{\prime} 4.6^{\prime \prime} \mathrm{E}\end{array}$ & $21^{0}$ & 1630 & $\begin{array}{l}\text { silt } \\
\text { loam }\end{array}$ \\
\hline 7 & $\begin{array}{l}\text { Gefetanua } \\
1\end{array}$ & Sodo Zuria & 1936 & $\begin{array}{l}06^{0} 53^{\prime} 12.7^{\prime \prime} \mathrm{N} \\
37^{0} 43^{\prime} 43.8 \mathrm{E}\end{array}$ & $20^{\circ}$ & 1340 & $\begin{array}{l}\text { Clay } \\
\text { loam }\end{array}$ \\
\hline 8 & *Wild11 & WSU & 1886 & $\begin{array}{l}06^{0} 49^{\prime} 55.4^{\prime \prime} \mathrm{N} \\
37^{0} 45^{\prime} 4.6^{\prime \prime} \mathrm{E}\end{array}$ & $21^{0}$ & 1630 & $\begin{array}{l}\text { silt } \\
\text { loam }\end{array}$ \\
\hline 9 & *Wild10 & WSU & 1886 & $\begin{array}{l}06^{0} 49^{\prime} 55.4^{\prime \prime} \mathrm{N} \\
37^{0} 45^{\prime} 4.6^{\prime \prime} \mathrm{E}\end{array}$ & $21^{0}$ & 1630 & $\begin{array}{l}\text { silt } \\
\text { loam }\end{array}$ \\
\hline 10 & GaGo71 & Areka & 1785 & $\begin{array}{l}07^{\circ} 04^{\prime} 02^{\prime \prime} \mathrm{N}, \\
37^{\circ} 41^{\prime} 22^{\prime \prime}, \mathrm{E}\end{array}$ & $20^{0}$ & 1400 & $\begin{array}{l}\text { silt } \\
\text { loam }\end{array}$ \\
\hline
\end{tabular}

*Mother plants originating from seeds collected in the wild, around Jimma $(\mathrm{N}$ 07'40'43", E36 50'19", 1739 m a.s.l.) and grown at Areka Research Centre until seed ripening (Karlsson et al., 2013a); WSU = Wolaita Sodo University 
22

Appendix Table 2 Morphological traits measured from enset landraces of the study area Wolaita zone, Ethiopia

\begin{tabular}{|l|l|l|}
\hline Character & Code & Qualitative categories or quantitative measure \\
\hline $\begin{array}{l}\text { Pseudostem } \\
\text { color }\end{array}$ & PSC & $\begin{array}{l}1=\text { light green, 2 = deep green, 3 = greenish black, 4 = light } \\
\text { red, 5 = dark red,6 = reddish yellow }\end{array}$ \\
\hline Petiole color & PC & $\begin{array}{l}1=\text { light green, 2 = deep green, 3 = yellowish green, 4 = light } \\
\text { red, 5 = dark red, 6 = reddish yellow }\end{array}$ \\
\hline Midrib color & MC & $\begin{array}{l}1=\text { light green, 2 = deep green, 3 = greenish yellow, 4 = } \\
\text { greenish red, 5 = light red, 6 = dark red, 7 = dark brown }\end{array}$ \\
\hline Leaf color & LC & $\begin{array}{l}1=\text { light green, 2 = deep green, 3 = light red, 4 = dark red, 5 = } \\
\text { purple }\end{array}$ \\
\hline Plant height & PH & Meter \\
\hline $\begin{array}{l}\text { Pseudostem } \\
\text { length }\end{array}$ & PSL & Meter \\
\hline $\begin{array}{l}\text { Pseudostem } \\
\text { circumference }\end{array}$ & PSC & Meter \\
\hline Leaf length & LL & Meter \\
\hline Leaf width & LW & Meter \\
\hline $\begin{array}{l}\text { Number of } \\
\text { leaves }\end{array}$ & NL & Number \\
\hline
\end{tabular}


Appendix table 3 chi-squared analysis of pseudostem color of the enset genotypes evaluated at WSU

\begin{tabular}{|c|c|c|c|c|}
\hline \multirow{2}{*}{$\begin{array}{l}\text { Enset clones } \\
\text { Arkia }\end{array}$} & \multicolumn{4}{|c|}{ Pseudostem color } \\
\hline & color & observed & expected & chi-square $(3: 1)$ \\
\hline & green & 12 & 12 & 0 \\
\hline & dark red & 4 & 4 & 0 \\
\hline & Total & 16 & 16 & 0 \\
\hline \multirow[t]{4}{*}{ Banga } & color & observed & expected & chi-square (1:3) \\
\hline & greenish black & 3 & 4 & 0.25 \\
\hline & dark red & 13 & 12 & 0.08 \\
\hline & Total & 16 & 16 & 0.33 \\
\hline \multirow[t]{4}{*}{ Gefetanuwa(2) } & color & observed & expected & chi-square (1:1) \\
\hline & light green & 7 & 8.5 & 0.264706 \\
\hline & reddish brown & 10 & 8.5 & 0.264706 \\
\hline & Total & 17 & 17 & 0.529412 \\
\hline \multirow[t]{4}{*}{ Wild 15 (Erpha) } & color & observed & expected & chi-square (3:1) \\
\hline & deep green & 15 & 13.5 & 0.166667 \\
\hline & light red & 3 & 4.5 & 0.5 \\
\hline & Total & 18 & 18 & 0.666667 \\
\hline \multirow[t]{4}{*}{ Alageena } & color & observed & expected & chi-square (1:3) \\
\hline & greenish black & 4 & 4 & 0 \\
\hline & red & 12 & 12 & 0 \\
\hline & Total & 16 & 16 & 0 \\
\hline \multirow[t]{5}{*}{ Wild 9} & color & observed & expected & chi-square (3:1) \\
\hline & green & 9 & 8.25 & 0.068182 \\
\hline & dark red & 24 & 24.75 & 0.022727 \\
\hline & Total & 33 & 33 & 0.090909 \\
\hline & color & observed & expected & chi-square \\
\hline Gefetanuwa (1) & red & 17 & & \\
\hline \multirow[t]{4}{*}{ Wild 11} & color & observed & expected & chi-square (1:3) \\
\hline & deep green & 3 & 4 & 0.25 \\
\hline & red & 13 & 12 & 0.08 \\
\hline & Total & 16 & 16 & 0.33 \\
\hline \multirow[t]{4}{*}{ Wild 10} & color & observed & expected & chi-square (1:3) \\
\hline & light green & 4 & 4 & 0 \\
\hline & dark red & 12 & 12 & 0 \\
\hline & Total & 16 & 16 & 0 \\
\hline \multirow[t]{4}{*}{ Gamogofa 71} & color & observed & expected & chi-square (1:3) \\
\hline & light green & 5 & 4.25 & 0.132 \\
\hline & red & 12 & 12.75 & 0.044 \\
\hline & Total & 17 & 17 & 0.176 \\
\hline
\end{tabular}


Appendix table 4 chi-squared analysis of petiole color of the enset genotypes evaluated at Wolaita Sodo University

\begin{tabular}{|c|c|c|c|c|}
\hline \multirow[t]{2}{*}{ Genotypes } & \multicolumn{4}{|c|}{ Petiole Color } \\
\hline & Color & observed & expected & chi-square $(1: 3)$ \\
\hline \multirow{3}{*}{ Arkia } & light green & 5 & 4 & 0.25 \\
\hline & red-purple & 11 & 12 & 0.08 \\
\hline & Total & 16 & 16 & 0.33 \\
\hline \multirow{4}{*}{ Banga } & Color & observed & expected & chi-square $(1: 3)$ \\
\hline & light green & 5 & 4 & 0.25 \\
\hline & light-dark red & 11 & 12 & 0.08 \\
\hline & Total & 16 & 16 & 0.33 \\
\hline \multirow{4}{*}{ Gefetanuwa(2) } & Color & observed & expected & chi-square $(1: 1)$ \\
\hline & light green & 7 & 8.5 & 0.264706 \\
\hline & greenish red & 10 & 8.5 & 0.264706 \\
\hline & Total & 17 & 17 & 0.529412 \\
\hline \multirow[t]{2}{*}{ Wild 15 (Erpha) } & Color & observed & expected & chi-square \\
\hline & greenish brown & 18 & & \\
\hline \multirow{4}{*}{ Alageena } & Color & observed & expected & chi-square $(1: 3)$ \\
\hline & light green & 4 & 4 & 0 \\
\hline & brown-red & 12 & 12 & 0 \\
\hline & Total & 16 & 16 & 0 \\
\hline \multirow{4}{*}{ Wild 9} & Color & observed & expected & chi-square (1:3) \\
\hline & Red & 6 & 8.25 & 0.613636 \\
\hline & dark brown & 27 & 24.75 & 0.204545 \\
\hline & Total & 33 & 33 & 0.818182 \\
\hline \multirow{2}{*}{ Gefetanuwa-1 } & Color & observed & expected & chi-square $(1: 3)$ \\
\hline & greenish red & 17 & & \\
\hline \multirow{4}{*}{ Wild 11} & Color & observed & expected & chi-square $(1: 3)$ \\
\hline & light red & 6 & 4 & 1 \\
\hline & greenish red & 10 & 12 & 0.333333 \\
\hline & Total & 16 & 16 & 1.333333 \\
\hline \multirow[t]{4}{*}{ Wild 10} & Color & observed & expected & chi-square $(1: 3)$ \\
\hline & Purple & 4 & 4 & 0 \\
\hline & greenish red & 12 & 12 & 0 \\
\hline & Total & 16 & 16 & 0 \\
\hline \multirow{4}{*}{ Gamogofa 71} & Color & observed & expected & chi-square (1:3) \\
\hline & light green & 4 & 4.25 & 0.132 \\
\hline & Red & 13 & 12.75 & 0.047 \\
\hline & Total & 17 & 17 & 0.179 \\
\hline
\end{tabular}


Appendix table 5 chi-squared analysis of midrib color of the enset genotypes evaluated at Wolaita Sodo University

\begin{tabular}{|c|c|c|c|c|}
\hline \multirow[t]{2}{*}{ Enset clones } & \multicolumn{4}{|c|}{ Midrib Color } \\
\hline & Color & observed & expected & chi-square $(1: 3)$ \\
\hline \multirow[b]{3}{*}{ Arkia } & Light green & 5 & 4 & 0.250 \\
\hline & red & 11 & 12 & 0.083 \\
\hline & Total & 16 & 16 & 0.333 \\
\hline \multirow[b]{4}{*}{ Banga } & Color & observed & expected & chi-square $(1: 3)$ \\
\hline & light green & 5 & 4 & 0.25 \\
\hline & brown-red & 11 & 12 & 0.08 \\
\hline & Total & 16 & 16 & 0.33 \\
\hline \multirow[b]{4}{*}{ Gefetanuwa(2) } & Color & observed & expected & chi-square $(1: 1)$ \\
\hline & light green & 10 & 8.5 & 0.264706 \\
\hline & greenish brown & 7 & 8.5 & 0.264706 \\
\hline & Total & 17 & 17 & 0.529412 \\
\hline \multirow[b]{2}{*}{ Wild 15 (Erpha) } & Color & observed & expected & chi-square \\
\hline & light red & 18 & & \\
\hline \multirow[b]{4}{*}{ Alageena } & Color & observed & expected & chi-square $(1: 3)$ \\
\hline & light green & 4 & 4 & 0 \\
\hline & red & 12 & 12 & 0 \\
\hline & Total & 16 & 16 & 0 \\
\hline \multirow{4}{*}{ Wild 9} & Color & observed & expected & chi-square (1:3) \\
\hline & light red & 6 & 8.25 & 0.613636 \\
\hline & dark brown & 27 & 24.75 & 0.204545 \\
\hline & Total & 33 & 33 & 0.818182 \\
\hline \multirow[b]{2}{*}{ Gefetanuwa-1 } & Color & observed & expected & chi-square $(1: 3)$ \\
\hline & red-brown & 17 & & \\
\hline \multirow{4}{*}{ Wild 11} & Color & observed & expected & chi-square $(1: 3)$ \\
\hline & light red & 6 & 4 & 1 \\
\hline & dark brown & 10 & 12 & 0.333333 \\
\hline & Total & 16 & 16 & 1.333333 \\
\hline \multirow[b]{4}{*}{ Wild 10} & Color & observed & expected & chi-square $(3: 1)$ \\
\hline & light red & 12 & 12 & 0 \\
\hline & dark brown & 4 & 4 & 0 \\
\hline & Total & 16 & 16 & 0 \\
\hline \multirow{4}{*}{ Gamogofa 71} & Color & observed & expected & chi-square $(1: 3)$ \\
\hline & green & 4 & 4.25 & 0.132 \\
\hline & red & 13 & 12.75 & 0.047 \\
\hline & Total & 17 & 17 & 0.179 \\
\hline
\end{tabular}


26

Appendix table 6 chi-squared analysis of leaf color of the enset genotypes evaluated at Wolaita Sodo University

\begin{tabular}{|c|c|c|c|c|}
\hline \multirow[t]{2}{*}{ Enset clones } & \multicolumn{2}{|c|}{ Leaf Color } & \multirow[b]{2}{*}{ expected } & \multirow[b]{2}{*}{ chi-square $(1: 3)$} \\
\hline & Color & observed & & \\
\hline \multirow[b]{3}{*}{ Arkia } & Light green & 0 & 4 & 4.0 \\
\hline & deep green & 16 & 12 & 1.33 \\
\hline & Total & 16 & 12 & 5.33 \\
\hline \multirow[b]{4}{*}{ Banga } & Color & observed & expected & chi-square $(1: 3)$ \\
\hline & light green & 5 & 4 & 0.250 \\
\hline & dark green & 11 & 12 & 0.083 \\
\hline & Total & 16 & 16 & 0.333 \\
\hline \multirow[b]{4}{*}{ Gefetanuwa (2) } & Color & observed & expected & chi-square $(1: 1)$ \\
\hline & light green & 7 & 8.5 & 0.264706 \\
\hline & deep green & 10 & 8.5 & 0.264706 \\
\hline & Total & 17 & 17 & 0.529412 \\
\hline \multirow[b]{2}{*}{ Wild 15 (Erpha) } & Color & observed & expected & chi-square \\
\hline & deep green & 18 & & \\
\hline \multirow[b]{4}{*}{ Alageena } & Color & observed & expected & chi-square $(1: 3)$ \\
\hline & light green & 4 & 4 & 0 \\
\hline & deep green & 12 & 12 & 0 \\
\hline & Total & 16 & 16 & 0 \\
\hline \multirow{2}{*}{ Wild 9} & Color & observed & expected & chi-square \\
\hline & deep green & 33 & & \\
\hline \multirow[b]{2}{*}{ Gefetanuwa-1 } & Color & observed & expected & chi-square $(1: 3)$ \\
\hline & deep green & 17 & & \\
\hline \multirow{2}{*}{ Wild 11} & Color & observed & expected & chi-square \\
\hline & deep green & 16 & & \\
\hline \multirow[b]{2}{*}{ Wild 10} & Color & observed & expected & chi-square \\
\hline & deep green & 16 & & \\
\hline \multirow{4}{*}{ Gamogofa 71} & Color & observed & expected & chi-square $(1: 3)$ \\
\hline & light green & 5 & 4.25 & 0.132 \\
\hline & deep green & 12 & 12.75 & 0.044 \\
\hline & Total & 17 & 17 & 0.176 \\
\hline
\end{tabular}

